\title{
Efficacy of biological agents and compost on growth and resistance of tomatoes to late blight
}

\author{
Amirhossein Bahramisharif ${ }^{1,2}(\mathbb{0}) \cdot$ Laura E. Rose $\mathrm{e}^{1,2,3}$
}

Received: 13 July 2018 / Accepted: 24 October 2018 / Published online: 7 November 2018

(c) The Author(s) 2018

\begin{abstract}
Main conclusion This study identified biocontrol measures for improving plant quality and resistance under biotic stress caused by the most devastating pathogen in tomato production.
\end{abstract}

The management of plant diseases are dependent on a variety of factors. Two important variables are the soil quality and its bacterial/fungal community. However, the interaction of these factors is not well understood and remains problematic in producing healthy crops. Here, the effect of oak-bark compost, Bacillus subtilis subsp. subtilis, Trichoderma harzianum and two commercial products (FZB24 and FZB42) were investigated on tomato growth, production of metabolites and resistance under biotic stress condition (infection with Phytophthora infestans). Oak-bark compost, B. subtilis subsp. subtilis, and T. harzianum significantly enhanced plant growth and immunity when exposed to $P$. infestans. However, the commercial products were not as effective in promoting growth, with FZB42 having the weakest protection. Furthermore, elevated levels of anthocyanins did not correlate with enhanced plant resistance. Overall, the most effective and consistent plant protection was obtained when B. subtilis subsp. subtilis was combined with oak-bark compost. In contrast, the combination of T. harzianum and oak-bark compost resulted in increased disease severity. The use of compost in combination with bio-agents should, therefore, be evaluated carefully for a reliable and consistent tomato protection.

Keywords Biocontrol $\cdot$ Phytophthora infestans $\cdot$ Plant-microbe interactions $\cdot$ Plant resistance $\cdot$ Secondary metabolites · Soil microbial community

\section{Introduction}

Cultivated tomato (Solanum lycopersicum L.) has a global production of 3.7 million hectares and is one of the most valuable agricultural crops worldwide (fao.org). However, tomatoes and nearly every crop species are also susceptible to a variety of pathogens that reduce both yield and quality. Late blight is the most devastating disease worldwide of both tomato and potato (Agrios 2005). Annual crop losses from

Laura E. Rose

laura.rose@hhu.de

1 Institute of Population genetics, Heinrich Heine University Duesseldorf, Universitaetsstr. 1, 26.03.00.25, 40225 Düsseldorf, Germany

2 International Graduate School in Plant Sciences (iGRAD-Plant), Düsseldorf, Germany

3 Cluster of Excellence on Plant Sciences (CEPLAS), Düsseldorf, Germany late blight are estimated at over five billion USD (Judelson and Blanco 2005; Haverkort et al. 2009). Late blight is caused by Phytophthora infestans (Mont.) de Bary. This pathogen belongs to the Oomycota, a distinct lineage of filamentous eukaryotes which are fungus-like. This pathogen infects multiple plant species in the Solanaceae, including potato and tomato (Fry et al. 2015). In the mid-19th century, $P$. infestans devastated the potato crop and caused the Irish potato famine (Fry et al. 2015). To this day, disease management remains difficult and requires integrated management strategies.

Late blight affects the leaves, stems, and fruits of tomato and can cause total crop loss within as little as 2 weeks. The most effective control of late blight is by chemical fungicides. Phenylamide fungicides, such as mefenoxam, have been used against $P$. infestans and provide an effective disease suppression (Saville et al. 2015). However, chemical applications have detrimental outcomes to environmental and human health (Schummer et al. 2012a, b). Another 
major problem with the use of fungicides is the evolution of fungicide resistance in $P$. infestans populations (Taylor et al. 2002; Matson et al. 2015). Therefore, fungicides cannot be used continuously and do not represent a sustainable method of control. To maintain crop yields, without damaging the environment and human health, organic amendments and biocontrol agents have been explored as alternatives to chemical fungicides.

In horticulture, the application of compost to soil improves soil structure and plant root growth and results in an overall increase in yield of several crops, such as tomato (Gutierrez-Miceli et al. 2007). Furthermore, compost provides essential plant nutrients such as nitrogen, phosphorus, and calcium and thereby reduces the need for synthetic fertilizers (Lewis et al. 1992; Iqbal et al. 2010). Composts can be made of raw feedstocks such as yard trimmings, food waste, manure, tree leaves/bark and worm castings (Termorshuizen et al. 2006). The antagonistic and biological effect of compost for disease suppression is quite well-known. Compost has been used as an organic treatment for disease suppression against many soilborne pathogens, including oomycete species, Rhizoctonia solani Kühn and Fusarium species in tomato, cauliflower, rooibos, oats, lupin, pine, and flax (Termorshuizen et al. 2006; Bahramisharif et al. 2013; Tewoldemedhin et al. 2015; Lamprecht and Tewoldemedhin 2017). Composts, such as non-aerated compost teas, have also shown significant suppressive effects on foliar pathogens, where mycelial growth of $P$. infestans was completely inhibited in vitro (Kone et al. 2010). However, information is limited on the use of compost to control P. infestans in greenhouse or field conditions. Various factors may influence disease suppression by composts and thus, the effect of compost is not always consistent. These factors include compost composition, microbial biomass, the rate of application and maturity (Termorshuizen et al. 2006; Janvier et al. 2007). On the other hand, the application of some composts may be problematic, especially those rich in saline, which have been shown to enhance oomycete disease severity (Hoitink et al. 1997). Therefore, the use of composts and their nutrient content must be carefully evaluated to achieve consistent plant growth and disease suppression.

Biological agents (bio-agents), defined as living organisms, can significantly lower the density of plant pathogens (O'Brien 2017). Biological control has therefore become very popular as a non-chemical alternative to control late blight disease. In the last three decades, numerous bacterial bio-agents have been evaluated for their ability to suppress P. infestans. These include: Bacillus amyloliquefaciens Priest et al., Bacillus cereus Frankland and Frankland, Bacillus pumilus Meyer and Gottheil, Bacillus subtilis Ehrenberg, and Pseudomonas fluorescens Migula (Yan et al. 2002; An et al. 2010; Chowdappa et al. 2013). Bacillus species have shown great potential to promote plant growth and suppress late blight in tomato. Kabir et al. (2013) evaluated 125 different soil microbes and described six strains of Bacillus that suppressed late blight by more than $60 \%$ on culture plates and in planta. They also showed that these bio-agents are able to enhance plant growth. Some of these bio-agents are known as plant growth promoting rhizobacteria (PGPRs). Two of the most effective PGPRs are B. subtilis and B. amyloliquefaciens. They are both Gram-positive bacteria, commonly found in soil. The PGPRs colonize the root and promote plant growth and most importantly enhance protection against plant pathogens. Furthermore, B. subtilis and B. amyloliquefaciens have been shown to stimulate the plant immune system by activating plant induced systemic resistance (ISR) and promote growth in several crops, including tomato (Kloepper et al. 2004; Chowdappa et al. 2013). Bacillus subtilis and $B$. amyloliquefaciens are both available as commercial products, marketed as Serenade ${ }^{\circledR}$ (B. subtilis, strain QST 713), FZB $24{ }^{\circledR} \mathrm{WG}$ (B. amyloliquefaciens, strain FZB24) and RhizoVital ${ }^{\circledR} 42$ (B. amyloliquefaciens, strain FZB42).

There are numerous fungal antagonists that are also available as potential biocontrol agents. The fungal agents that are capable of suppressing P. infestans include Fusarium oxysporum Schlecht. emend. Snyder and Hansen, Pythium oligandrum Dreschler and Trichoderma species (Kim et al. 2007; Horner et al. 2012; Yao et al. 2016). Trichoderma harzianum Rafai and $P$. oligandrum have been reported to suppress the pathogen through competition, promoting plant growth and antibiosis or through mycoparasitism (Benhamou et al. 1999; Benitez et al. 2004). Similar to PGPRs, Trichoderma species stimulate plant immunity which may result in an activation of ISR in plants. Several studies have reported that T. harzianum upregulated induced defense response in different plants, including maize and tomato (Martinez-Medina et al. 2013; Saravanakumar et al. 2016).

While a few studies have shown that the use of organic amendments such as compost in combination with nonpathogenic species or biocontrol agents could significantly improve the disease suppression caused by highly virulent soilborne pathogens (Hoitink and Boehm 1999; Bahramisharif et al. 2013), the complex and inconsistent management of biological control has not translated into widespread use in field crops (Ryan et al. 2004; Xu et al. 2011). In particular, the potential of a combination compost and biological control treatment in tomato protection has not been fully exploited. The aim of this study was to identify reliable methods for improving plant resistance under biotic stress in tomato production. We evaluated (1) the effect of biological agents and commercial products on tomato growth, stress response and protection, (2) the potential of oak-bark compost as a standalone treatment or in combination with bio-agents in plant growth, stress and protection, and (3) 
whether a combination of the compost with the biological agents or the commercial products increases consistency.

\section{Materials and methods}

\section{Biological agents}

In this study, two biocontrol agents were tested for the ability to control late blight disease in tomato: Bacillus subtilis subsp. subtilis and Trichoderma harzianum. The Bacillus subtilis subsp. subtilis isolate DSM-10 was sourced from the Deutsche Sammlung von Mikroorganismen und Zellkulturen (Braunschweig, Germany). The T. harzianum isolate CBS 354.33 was obtained from the Centraalbureau voor Schimmelcultures (Utrecht, The Netherlands). Furthermore, two commercial products containing B. amyloliquefaciens ssp. plantarum: FZB $24{ }^{\circledR} \mathrm{WG}$ and RhizoVital ${ }^{\circledR} 42 / \mathrm{FZB} 42$ were used. Both products were purchased from ABiTEP-Biotech for Agriculture and Ecology (Berlin, Germany).

\section{Isolation and sporulation of Trichoderma harzianum}

The T. harzianum isolate CBS 354.33 was grown on Trichoderma-selective media (Williams et al. 2003). The culture was incubated at $24{ }^{\circ} \mathrm{C}$ for 30 days in darkness. For sporulation of the isolate, the culture was plated out onto potatodextrose agar (PDA) and incubated at $24{ }^{\circ} \mathrm{C}$ for 20 days.

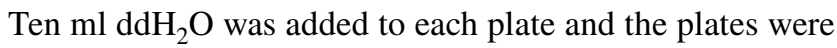
carefully sealed and incubated at room temperature for up to $2 \mathrm{~h}$. The spores were then harvested as previously described (Perelló et al. 2009). The spore concentration was measured with a hemacytometer and a suspension with a concentration of $5 \times 10^{8}$ spores per $\mathrm{ml}$ was prepared and used immediately.

\section{Isolation and sporulation of Bacillus spp.}

Bacillus subtilis subsp. subtilis isolate DSM-10 was received as a freeze-dried culture. Following the supplier's instructions, the dried pellet was rehydrated with $0.5 \mathrm{ml}$ of nutrient broth. After $30 \mathrm{~min}$ of incubation at room temperature, the content was gently mixed and about half of the content was transferred into a $5 \mathrm{ml}$ tube containing nutrient broth. The other half was streaked onto nutrient agar plates and used for storage. The broth cultures were incubated on rotary shaker at $200 \mathrm{rpm}$ at $30{ }^{\circ} \mathrm{C}$ (Nakamura et al. 1999) until the logarithmic phase was reached. The $\mathrm{OD}_{600}$ value was calculated using a DeNovix DS-11 FX spectrophotometer (DeNovix Inc., Wilmington, DE, USA). The suspension was diluted to reach the concentration of $5 \times 10^{8}$ colony forming units per $\mathrm{ml}(\mathrm{CFU} / \mathrm{ml})$.

The two commercial products, FZB $24{ }^{\circledR} \mathrm{WG}$ and RhizoVital $^{\circledR} 42 /$ FZB42, contain living spores of $B$. amyloliquefaciens ssp. plantarum. These products were first diluted in $\mathrm{ddH} 2 \mathrm{O}$ and $100 \mu \mathrm{l}$ of the suspension was streaked on Luria-Bertani broth (LB) medium containing 1.5\% agar. The cultures were incubated at $30{ }^{\circ} \mathrm{C}$ for 2 days and the bacterial cells were then harvested and grown in LB. The broth cultures were incubated at $30^{\circ} \mathrm{C}$ overnight on rotary shaker (at $200 \mathrm{rpm}$ ). The spore concentration of $5 \times 10^{8} \mathrm{CFU} / \mathrm{ml}$ was prepared exactly as for DSM-10 and used immediately.

\section{Biomass and plant height}

To evaluate the effect of the treatments on plant growth, 3 -week-old tomato plants were first carefully removed from the pots. The soil adhering to the roots was removed by gentle shaking and the remaining rhizosphere soil was brushed off into a $50 \mathrm{ml}$ falcon tube for DNA extraction. The root was washed with water thoroughly to remove soil particles adhering to the root. Root and shoot length, as well as, fresh weight was then determined for all plants.

\section{Efficacy of biocontrol}

Twelve different treatments were evaluated for their ability to enhance plant growth and/or to suppress disease (Table 1). Each treatment had nine biological replicates, of which three were used to evaluate growth and six were used to evaluate disease suppression. The experiment was replicated two times. The replicates were carried out in a growth chamber under standard growing conditions for tomatoes. The

Table 1 The 12 treatments that were used to test for growth promotion and disease suppression

\begin{tabular}{|c|c|c|c|c|c|}
\hline \multirow[t]{3}{*}{ Treatments } & \multicolumn{5}{|c|}{ Biological control } \\
\hline & \multirow[t]{2}{*}{$\begin{array}{l}\text { Compost } \\
\text { amended }\end{array}$} & \multicolumn{2}{|c|}{ Biological agents } & \multicolumn{2}{|c|}{$\begin{array}{l}\text { Commercial } \\
\text { products }\end{array}$} \\
\hline & & $\begin{array}{l}\text { Bacillus sub- } \\
\text { tilis subsp. } \\
\text { subtilis }\end{array}$ & $\begin{array}{l}\text { Tricho- } \\
\text { derma } \\
\text { harzianum }\end{array}$ & FZB24 & FZB42 \\
\hline T0/control & $\ldots$ & $\ldots$ & $\ldots$ & $\ldots$ & $\ldots$ \\
\hline $\mathrm{T} 1$ & $\times$ & $\ldots$ & $\ldots$ & $\ldots$ & $\ldots$ \\
\hline $\mathrm{T} 2$ & $\ldots$ & $x$ & $\ldots$ & $\ldots$ & $\ldots$ \\
\hline $\mathrm{T} 3$ & $\times$ & $x$ & $\ldots$ & $\ldots$ & $\ldots$ \\
\hline $\mathrm{T} 4$ & $\ldots$ & $\ldots$ & $\ldots$ & $\times$ & $\ldots$ \\
\hline T5 & $\times$ & $\ldots$ & $\cdots$ & $x$ & $\cdots$ \\
\hline T6 & $\cdots$ & $\cdots$ & $\cdots$ & $\cdots$ & $\times$ \\
\hline $\mathrm{T} 7$ & $\times$ & $\ldots$ & $\cdots$ & $\ldots$ & $x$ \\
\hline $\mathrm{T} 8$ & $\ldots$ & $\ldots$ & $\times$ & $\ldots$ & $\ldots$ \\
\hline T9 & $\times$ & $\ldots$ & $x$ & $\ldots$ & $\ldots$ \\
\hline $\mathrm{T} 10$ & $\times$ & $x$ & $x$ & $\cdots$ & $\cdots$ \\
\hline T11 & $x$ & $x$ & $\times$ & $x$ & $\times$ \\
\hline
\end{tabular}


replicates followed a randomized block design with the placement of the pots being changed every 7 days.

Five treatments contained un-amended soil (Stender ${ }^{\circledR}$ C-400 with Cocopeat) and seven treatments contained the same soil amended with $25 \%$ v/v of oak-bark compost. For all treatments, $11-\mathrm{cm}$ diameter plastic pots were filled with approximately $1 \mathrm{~kg}$ of either soil or the soil amended with compost. One hole with a depth of $1.5 \mathrm{~cm}$ was made in the soil using $1 \mathrm{~cm}$ diameter sterile doweling rods. Directly before planting the tomato seed, $1 \mathrm{ml}$ of biocontrol agent suspension was pipetted into the hole according to the treatment. Combined treatments received $1 \mathrm{ml}$ suspension for all agents. Directly afterwards, one tomato seed (cv. Moneymaker) was planted into the hole and covered.

\section{Isolation and sporulation of $P$. infestans}

The highly virulent $P$. infestans isolate, D 12-2, was obtained from Francine Govers' Laboratory of Phytopathology (Wageningen University, The Netherlands). This isolate was grown on Rye B Agar (Caten and Jinks 1968). The medium was prepared with $60 \mathrm{~g}$ of rye grain soaked in $\mathrm{ddH}_{2} \mathrm{O}$ for $24 \mathrm{~h}$. The supernatant was then removed and $11 \mathrm{ddH}_{2} \mathrm{O}$ was added. The mixture was then boiled for $2 \mathrm{~h}$ in a 21 sterile beaker. The supernatant was filtered through cheesecloth and combined with the original supernatant. Then, $15 \mathrm{~g}$ of Bacto agar, $20 \mathrm{~g}$ of sucrose and $0.05 \mathrm{~g}$ beta-sitosterol were added to the supernatant and autoclaved at $15 \mathrm{psi}$ for $20 \mathrm{~min}$. Following incubation on plates at $18{ }^{\circ} \mathrm{C}$ for 20 days in darkness, $10 \mathrm{ml}$ of cold $\mathrm{ddH}_{2} \mathrm{O}$ was used to harvest $P$. infestans sporangia. A zoospore suspension was then prepared by placing the suspension at $4{ }^{\circ} \mathrm{C}$ for $2-4 \mathrm{~h}$ until the zoospores were released (de Vries et al. 2017). A suspension with a total concentration of $5 \times 10^{5}$ zoospores $/ \mathrm{ml}$ was prepared for infection using a hemacytometer.

\section{Plant biotic stress assays (whole plant and detached leaf infection assays)}

Whole plant infections were done on 3-week-old tomato plants using artificial inoculation technique as follows: Ten $\mu \mathrm{l}$ of the $P$. infestans zoospore suspension $\left(5 \times 10^{5}\right.$ zoospores $/ \mathrm{ml}$ ) was carefully infiltrated into the extracellular space of five young leaves using a $1 \mathrm{ml}$ needleless syringe. For the control plants, $10 \mu \mathrm{l}$ of $\mathrm{ddH}_{2} \mathrm{O}$ was infiltrated into five leaves using the same technique. The inoculated leaflets were collected after 5 days. Re-isolation was made from the leaflet and root fulfilling Koch's postulates.

In the detached leaf infection assay, five young leaves from 3-week-old plants were excised and placed in a Petri dish, containing a wet sterile paper towel. Ten $\mu$ lof the zoospore suspension $\left(5 \times 10^{5}\right.$ zoospores $\left./ \mathrm{ml}\right)$ was loaded onto the abaxial surface of detached leaves. For the control plants,
$10 \mu \mathrm{l}$ of $\mathrm{ddH}_{2} \mathrm{O}$ was loaded. The Petri dishes were kept at $18{ }^{\circ} \mathrm{C}$ in the dark for 5 days.

\section{Screening of necrotic lesions by $P$. infestans}

For both the whole plant and detached leaf assays, all inoculated leaves were bleached using $100 \% \mathrm{EtOH}$ for $72 \mathrm{~h}$. After bleaching out the chlorophyll, the necrotic lesions were examined under a SteREO Discovery V8 binocular (AxioCam ICc 5 camera; Zeiss, Jena, Germany) and quantified with the ZEN lite 2012 software (Zeiss).

\section{Defense-related compounds}

Anthocyanins, phenolic flavonoid pigments, are synthesized by the phenylpropanoid pathway and may be induced in response to plant stress. To determine whether the compost or the bio-agents affected the level of anthocyanin production in the leaves, the anthocyanin content was evaluated as previously described (Lindoo and Caldwell 1978). Six biological replicates were used for each treatment.

\section{Design of specific primers for T. harzianum and $B$. subtilis subsp. subtilis}

The ITS sequence of T. harzianum (CBS 354.33; AF278790) and 16S rRNA sequences of $B$. subtilis subsp. subtilis (DSM-10; LN681568), B. amyloliquefaciens strains FZB24 (AY055219) and FZB42 (AY055221) were downloaded from GenBank (https://www.ncbi.nlm.nih.gov) and uploaded into Geneious ${ }^{\circledR}$ 11.0.2 (Kearse et al. 2012). Species-specific primers were designed for all sequences using the Geneious plugin Primer 3 2.3.7 (Rozen and Skaletsky 2000) (Table 2).

\section{DNA extraction and PCR amplification of $P$. infestans and $T$. harzianum isolates}

For positive controls of the PCR amplification, Phytophthora infestans was grown on $20 \%$ unclarified V8 Agar

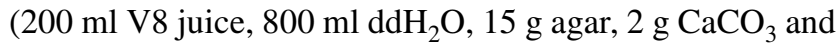
$0.05 \mathrm{~g}$ beta-sitosterol) for 14 days and T. harzianum was grown on PDA for 7 days. Mycelium from both were then harvested and genomic DNA (gDNA) was extracted using the extraction method described by Edwards et al. (1991).

For DNA amplification of $P$. infestans, the cytochrome $c$ oxidase subunit II (COX2) region was used (Hudspeth et al. 2000; Table 2). For T. harzianum, DNA was amplified for the specific primers described above. Polymerase chain reaction (PCR) was conducted in a total volume of $20 \mu \mathrm{l}$ consisting of Green GoTaq ${ }^{\circledR}$ Flexi Buffer, 2 U GoTaq ${ }^{\circledR}$ Flexi DNA Polymerase (Promega, Fitchburg, WI, USA), $1.25 \mathrm{mM} \mathrm{MgCl}_{2}, 0.1 \mathrm{mM}$ dNTPs and $0.2 \mathrm{mM}$ of each primer. The T100 ${ }^{\mathrm{TM}}$ Thermal 
Table 2 The universal and species-specific primers used in PCR analyses

\begin{tabular}{lll}
\hline Primers & Sequence 5'-3' & References \\
\hline ITS6-F & GAAGGTGAAGTCGTAACAAGG & Cooke et al. (2000) \\
ITS4-R & TCCTCCGCTTATTGATATGC & White et al. (1990) \\
Cox2-F & GGCAAATGGGTTTTCAAGATCC & Hudspeth et al. (2000) \\
Cox2-R & CCATGATTAATACCACAAATTTCACTAC & Hudspeth et al. (2000) \\
V5F primer (785F) & GGATTAGATACCCTGGTA & Arenz et al. (2015) \\
V6R primer (1064R) & CGACRRCCATGCANCACCT & Arenz et al. (2015) \\
CBS354-F & TGAAGAACGCAGCGAAATGC & Current study \\
CBS354-R & GCGAGTGTGCAAACTACTGC & Current study \\
DSM10-F & CCACACTGGGACTGAGACAC & Current study \\
DSM10-R & ACTTAAGAAACCGCCTGCGA & Current study \\
FZB-F & GTGAGGTAACGGCTCACCAA & Current study \\
FZB-R & GTGTCTCAGTCCCAGTGTGG & Current study \\
\hline
\end{tabular}

Cycler (Bio-Rad, Hercules, CA, USA) was used for amplification of $P$. infestans with PCR condition as follows: initial denaturation at $95{ }^{\circ} \mathrm{C}$ for $3 \mathrm{~min}, 34$ cycles of $95{ }^{\circ} \mathrm{C}$ for $30 \mathrm{~s}$, annealing for $30 \mathrm{~s}$ at $60{ }^{\circ} \mathrm{C}$, extension at $72{ }^{\circ} \mathrm{C}$ for $1.30 \mathrm{~min}$, and final extension at $72{ }^{\circ} \mathrm{C}$ for $5 \mathrm{~min}$. The PCR for T. harzianum was carried out with initial denaturation at $94{ }^{\circ} \mathrm{C}$ for $5 \mathrm{~min}, 32$ cycles of $94^{\circ} \mathrm{C}$ for $30 \mathrm{~s}$, annealing for $30 \mathrm{~s}$ at $55^{\circ} \mathrm{C}$, extension at $72{ }^{\circ} \mathrm{C}$ for $1.30 \mathrm{~min}$, and final extension at $72{ }^{\circ} \mathrm{C}$ for $7 \mathrm{~min}$. Gel electrophoresis was analyzed by resolving PCR products in $1 \%$ agarose gel and DNA was stained using Midori Green Advance (Nippon Genetics Europe, Dueren, Germany).

\section{DNA extraction and PCR amplification from bacterial isolates}

The bacterial cells of DSM-10 were harvested from nutrient agar and then added into nutrient broth. For FZB24 and FZB42, the cells were harvested from LB medium. The broth media were incubated at $30^{\circ} \mathrm{C}$ for overnight on rotary shaker at $200 \mathrm{rpm}$. Chromosomal DNA was then extracted using DNeasy ${ }^{\circledR}$ PowerLyzer ${ }^{\circledR}$ Microbial Kit (Qiagen, Hilden, Germany) following the manufacturer's protocol. For the amplification of $16 \mathrm{~S}$ rDNA, the universal primers V5F and V6R (Arenz et al. 2015) and newly designed primers were used (Table 2). PCR was carried out in the T100 ${ }^{\mathrm{TM}}$ Thermal Cycler (Bio-Rad) with initial denaturation at $94{ }^{\circ} \mathrm{C}$ for $9 \mathrm{~min}$, following 30 cycles of $94^{\circ} \mathrm{C}$ for $30 \mathrm{~s}, 57^{\circ} \mathrm{C}$ for $30 \mathrm{~s}$, $72{ }^{\circ} \mathrm{C}$ for $45 \mathrm{~s}$, and the final extension for $7 \mathrm{~min}$ at $72^{\circ} \mathrm{C}$. To conduct gel electrophoresis, PCR products were resolved in $1 \%$ agarose gel and DNA was visualized by staining with Midori Green Advance (Nippon Genetics Europe).

\section{DNA extraction from rhizosphere soil and plant material}

To evaluate relative abundance of different species in rhizosphere soil and plant material, gDNA was extracted from rhizosphere soil using DNeasy ${ }^{\circledR}$ PowerSoil ${ }^{\circledR}$ Kit (Qiagen), and roots and leaves using DNeasy ${ }^{\circledR}$ PowerPlant ${ }^{\circledR}$ Pro Kit (Qiagen) according to manufacturer's instructions. PCR was conducted for screening for the presence of $P$. infestans and the bio-agents using the same PCR conditions as described above.

\section{Cloning and sequencing}

To investigate the microbial community in oak-bark compost, gDNA was extracted from the compost using DNeasy ${ }^{\circledR}$ PowerSoil $^{\circledR}$ Kit (Qiagen). PCR was conducted for amplification of DNA for the ITS and 16S rDNA regions with the same conditions as described above. The PCR product of compost's DNA was purified using peqGOLD CyclePure kit (VWR, Peqlab, Radnor, PA, USA). The purified PCR product was then cloned using TOPO $^{\circledR}$ TA cloning $^{\circledR}$ kit (Thermo Fisher Scientific, Waltham, MA, USA) following the manufacturer's instructions. To screen the microbial community, sequencing analyses of the ITS and 16S rDNA regions of three clones were carried out by Eurofins Genomics DNA sequencing facility (Eurofins Genomics, Ebersberg, Germany). For the ITS region, the universal primers ITS6 (Cooke et al. 2000) and ITS4 (White et al. 1990) were used, and $16 \mathrm{~S}$ rDNA region was amplified using primers V5F and V6R (Table 2).

\section{Statistical analyses}

To test for statistical differences between treatments, oneway ANOVA was performed for all the phenotypic measurements, including shoot and root length, plant fresh weight and necrotic area. Levene's test was conducted for homogeneity of two repeat trials (Levene 1961). Independentsamples $t$ test was performed to compare the variances of all pairwise combinations. The Shapiro-Wilk's test was conducted to test for deviations from normality (Shapiro and 
Wilk 1965). Tukey's HSD (Honest significance different) test was calculated for each of these phenotypic measurements as well as anthocyanin content to determine significant differences at 5\% level (Tukey 1949). All the procedures were performed by IBM SPSS Statistics software (version 25).

\section{Results}

\section{Growth promotion by oak-bark compost and bio-agents}

The null hypothesis of the Levene's test could not be rejected $(P>0.05)$; therefore, the data from the two repeat trials were combined. The Shapiro-Wilk's test showed that growth data do not fit the normal distribution. Thus, before the analysis of variance, the data were transformed to meet the assumption of normality using logarithmic transformation. According to the one-way analysis of variance plant growth differed significantly across treatments (Table 3 ).

Treatments with oak-bark compost and certain bio-agents significantly increased tomato growth (Figs. 1 and 2). The compost-treated plants (T1) were the largest. Compared to the control plants (T0), plants grown with compost (T1) had 3.7-fold longer roots, 1.4-fold longer shoots and 3.3-fold greater fresh weight (Figs. 1, 2a-e). The two bio-agents, $B$. subtilis subsp. subtilis (T2) and T. harzianum (T8), significantly enhanced plant growth compared to the control (T0) (Figs. 1, 2a, b, e). The biomass was, however, larger by $B$. subtilis subsp. subtilis (T2) than T. harzianum (T3). The FZB24 product (T4) was better in promoting plant growth than FZB42 (T6). Treatment with FZB24 (T4) significantly improved root growth and fresh weight, while treatment with FZB42 (T6) did not significantly promote plant growth compared to the untreated control (T0) (Figs. 1, 2c-e).

Table 3 Analyses of variance (ANOVA) for the effect of 12 treatments (T0-T11) on plant growth and necrotic area in whole plant and detached leaf assays

\begin{tabular}{lllll}
\hline Parameter & $d f^{\mathrm{a}}$ & $\mathrm{MS}^{\mathrm{b}}$ & $F$ & $\mathrm{SL}^{\mathrm{c}}$ \\
\hline Root length & 11 & 0.025 & 6.029 & $<0.0001$ \\
Shoot length & 11 & 0.003 & 5.774 & $<0.0001$ \\
Fresh weight & 11 & 0.017 & 7.424 & $<0.0001$ \\
Whole plant assay & 11 & 0.173 & 4.161 & $<0.0001$ \\
Detached leaf assay & 11 & 0.079 & 5.282 & $<0.0001$ \\
Anthocyanin content & 11 & 0.045 & 3.190 & 0.002 \\
\hline
\end{tabular}

${ }^{\mathrm{a}}$ Degrees of freedom

${ }^{\mathrm{b}}$ Mean squares

${ }^{\text {c }}$ Significant level of the $F$ ratio

\section{Growth promotion by combination treatments}

The assays showed that the combination of the compost and bio-agents or commercial products can further increase plant growth (Figs. 1, 2). B. subtilis subsp. subtilis in combination with compost (T3) enhanced plant growth, compared to the stand-alone treatment with $B$. subtilis subsp. subtilis (T2) (Figs. 1, 2a). Compared to the control plants (T0), plants grown with a combination of oak-bark compost and $B$. subtilis subsp. subtilis (T3) had 3.8-fold longer roots, 1.6-fold longer shoots and 3.5-fold greater fresh weight (Figs. 1, 2a, e). Plants treated with FZB24 and compost (T5) had significantly longer shoots compared to the untreated control (T0) and had 1.2-fold longer shoots than in the standalone treatment with FZB24 (T4) (Figs. 1, 2c). Although FZB42 (T6) did not significantly stimulate plant growth compared to the untreated control, shoot length and fresh weight were significantly enhanced, when this commercial product was combined with the compost (T7) (Figs. 1, 2d).

\section{Plant protection by oak-bark compost and bio-agents in whole plant assay}

Based on Levene's test, variance from the two repeat trials were comparable and, thus data were combined. The normality test by Shapiro-Wilk was rejected for the necrotic area data and therefore, the data was transformed to meet the assumption of normality using logarithmic transformation. Strong evidence for significant interactions was observed across treatments (Table 1).

All of the treatments evaluated in this study (T1-T11), except treatment $\mathrm{T} 9$, protected tomato plants from the disease (Fig. 3), while the untreated control plants remained highly susceptible to $P$. infestans (Fig. 4a, c). Oak-bark compost, as a stand-alone treatment (T1), suppressed the disease by $82 \%$ on average. The highest suppression of late blight (85\%) was achieved in the treatment with B. subtilis subsp. subtilis (T2), but T. harzianum (T8) and FZB24 (T4) also showed high disease suppression (80\% and 79\%, respectively). In contrast, FZB42 (T6) was the least effective of all treatments, averaging $70 \%$ disease suppression.

\section{Plant protection by co-inoculation of oak-bark compost and bio-agents in whole plant assay}

The biological agents, in combination with the compost, improved plant protection, but not for all of the treatments (Fig. 3). Late blight disease severity decreased, on average, by $8 \%$ when the compost was combined with $B$. subtilis subsp. subtilis (T3) (Fig. 4b, e). Furthermore, the variance was significantly lower in combination treatments of compost with B. subtilis subsp. subtilis (T3), indicating consistent disease control. However, the combination of $T$. 
Fig. 1 Effect of the 12 treatments on root length, shoot length and fresh weight of tomato plants. The treatments were as follows: T0 (untreated control), T1 (compost), T2 (B. subtilis subsp. subtilis), T3 (compost + B. subtlis subsp. subtilis), T4 (FZB24), T5 (compost +FZB24), T6 (FZB42), T7 (compost+FZB42), T8 (T. harzianum), T9 (compost $+T$. harzianum), T10 (compost $+B$. subtlis subsp. subtilis $+T$. harzianum), T11 (compost $+B$. subtlis subsp. subtilis $+T$. harzianum +FZB24+FZB42). Data are from three replicates over two trials. The treatments that differ significantly from the untreated control are indicated in blue and the treatments that do not differ significantly from untreated control are indicated in red. Boxplots with the same letters do not differ significantly at $P=0.05$

harzianum with compost (T9) resulted in a $23 \%$ increase in disease severity compared to T. harzianum alone (T8). The addition of $B$. subtilis subsp. subtilis to the treatment including $T$. harzianum and compost (T10) increased the suppression by $16 \%$ relative to T9. Furthermore, the negative impact of the combination of compost and T. harzianum was nullified when the bio-agents and commercial products were combined (T11), a treatment which resulted in an average total suppression of $80 \%$, compared to the untreated control (T0).

\section{Plant protection in detached leaf assay}

In the detached leaf assay, oak-bark compost (T1) suppressed late blight disease by $71 \%$ and by B. subtilis subsp. subtilis (T2) suppressed late blight disease by $76 \%$ compared to the untreated control plants (T0) (Fig. 3). Furthermore, in the combined treatments, only treatments T3 and T10 reduced late blight incidence compared to the untreated control (T0) (Figs. 3, 4f). Similar to the whole plant assays, the disease severity was higher when T. harzianum was combined with the compost (T9) than T. harzianum as a standalone treatment (T8); the T. harzianum treatment (T8) was unable to significantly reduce the disease. The commercial products, FZB24 and FZB42, were not effective in suppressing the disease, either as a stand-alone treatment or in combination with the compost.

\section{Analysis of anthocyanins}

The influence of oak-bark compost, biological agents and the commercial products on the accumulation of anthocyanin was determined. The anthocyanin content was significantly higher in the plants that were treated with FZB24 (T4), FZB42 (T6), and T. harzianum (T8) compared to the untreated control (Fig. 5). In the combined treatment assays, only treatments containing $T$. harzianum (T9, T10 and T11) had significantly higher anthocyanin content over the untreated control (T0) (Fig. 5). Interestingly, the plants with higher accumulation of anthocyanin pigments appeared to have much darker leaves.
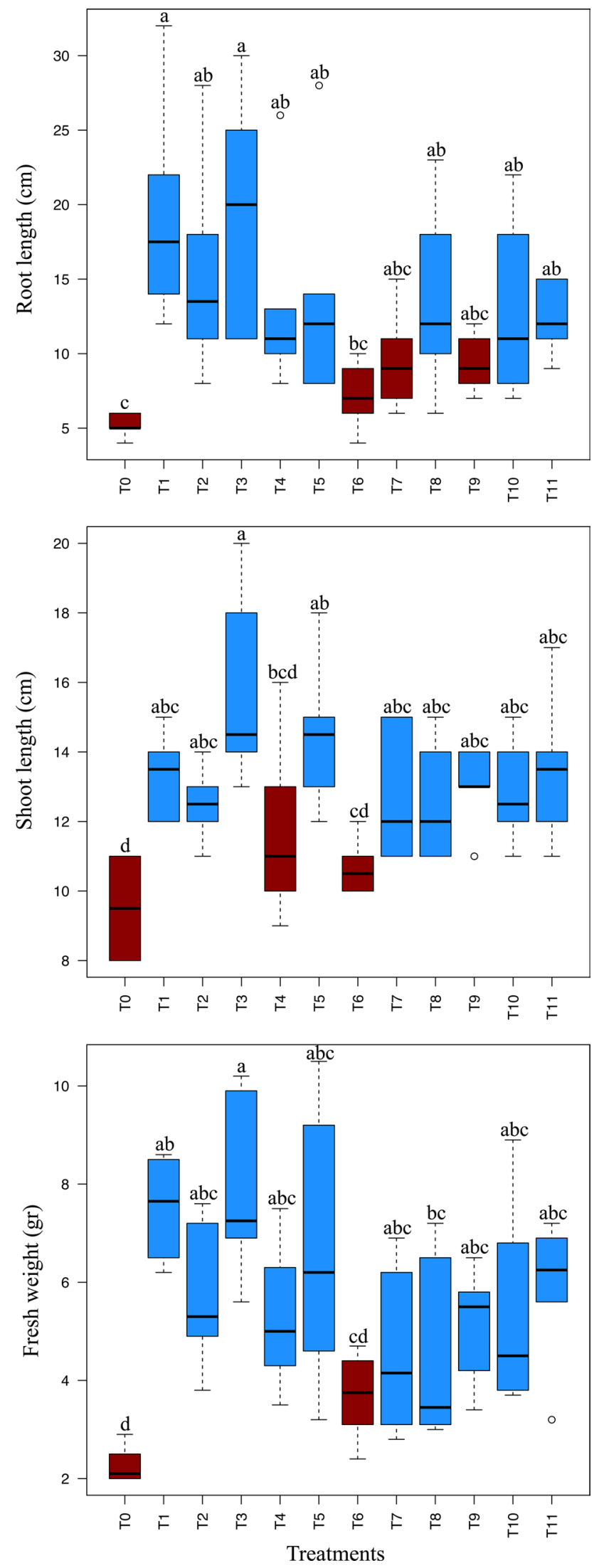
Fig. 2 Effect on tomato growth of treatments with $B$. subtlis subsp. subtilis (DSM-10, a); T. harzianum (CBS354.33, b); FZB24 (c) and FZB42 (d). e Effect of the 12 treatments on root growth
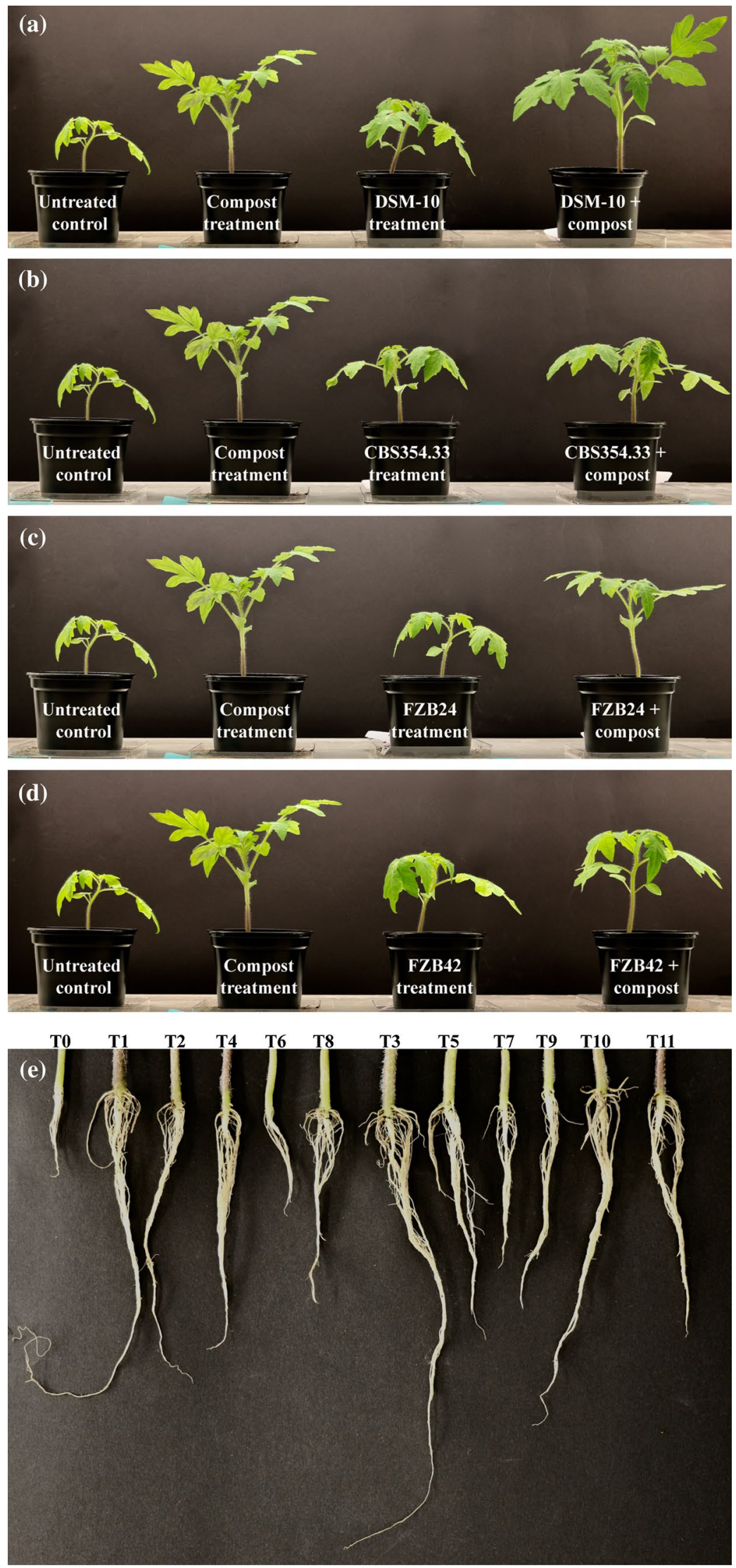

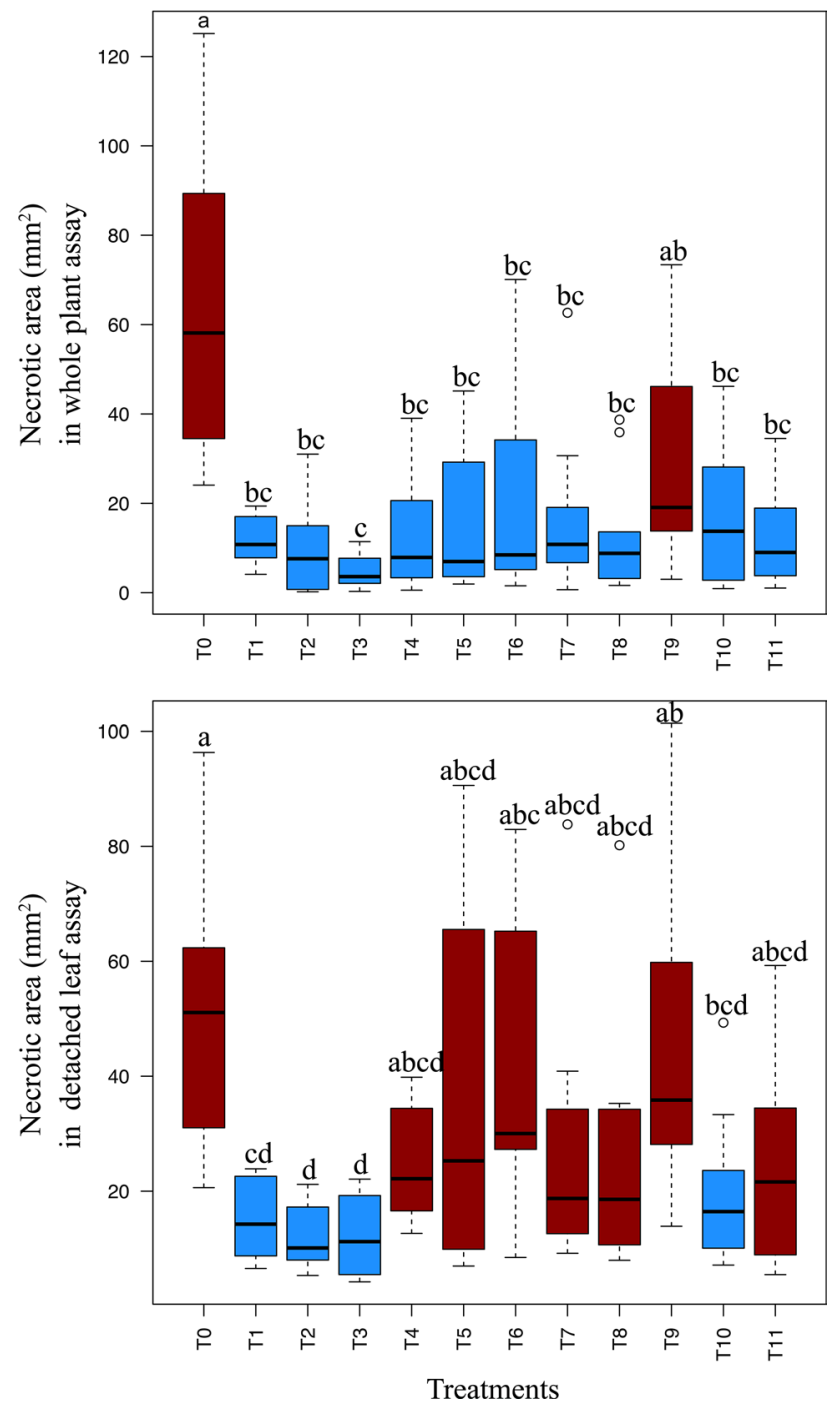

Fig. 3 Necrotic area for 12 treatments (T0-T11) in the whole plant and detached leaf assays. Data are from five replicates over two trials. The treatments that differ significantly from the untreated control are indicated in blue and the treatments that do not differ significantly from untreated control are indicated in red. Boxplots with the same letters do not differ significantly at $P=0.05$

\section{Detection of pathogen and biological agent DNA in rhizosphere soil and plant material}

The presence of $P$. infestans, as well as the bio-agents and commercial products, was determined in the leaf tissue, root and rhizosphere soil for all treatments using specific DNA markers. Phytophthora infestans was detected in all $P$. infestans-inoculated plants (i.e., in both the whole plant and detached leaf assays). P. infestans was not detected in the untreated control plants for either assay. The biological agents, B. subtilis subsp. subtilis and T. harzianum, and the commercial products, FZB24 and FZB42, were detected in both roots and soil from the plants treated with the corresponding microbe. None of the microbes were detected in the extractions from leaves of the treated plants.

\section{Screening of microbial community in oak-bark compost}

To determine the presence of microbes in the oak-bark compost, the microbial community of the compost was screened. Multiple clones were sequenced. ITS amplicons corresponded to: Antennariella placitae Cheewangkoon and Crous, Mortierella elongata Linnem. and Phialophora cyclaminis J.F.H. Beyma. 16S rDNA amplicons corresponded to Enterobacter cloacae Hormaeche and Edwards, Paenibacillus validus Ash et al. and uncultured bacteria. This indicated that additional microbes may have played a role in disease suppression in treatments containing oak-bark compost.

\section{Discussion}

The present study showed that the oak-bark compost not only promotes plant growth, but also protects plants when exposed to $P$. infestans. The use of compost has become very popular as a cultural practice to improve soil health, promote growth and suppress disease. Composts are made from different source materials and, therefore, depending on the type of the compost, their effect on plant growth and/or disease suppression can vary (Termorshuizen et al. 2006). The influence of composts in suppression of soilborne pathogens, such as fungi and oomycetes is quite well-known (Hoitink and Boehm 1999; Termorshuizen et al. 2006; Bahramisharif et al. 2013; Tewoldemedhin et al. 2015). The use of soil amendments to control foliar pathogens is, however, not widely studied. A few studies have shown that nonaerated compost teas, which are fermented watery extracts, were able to inhibit the growth of Ralstonia solanacearum (Smith) Yabuuchi et al. in greenhouse trials and Alternaria solani Sorauer, Botrytis cinerea Pers. and P. infestans in in vitro assays (Kone et al. 2010; Mengesha et al. 2017). However, this study showed that compost as a stand-alone soil treatment has the potential to protect tomato plants from P. infestans.

Several factors can contribute to growth promotion and plant protection by compost. These factors can be divided into direct and indirect mechanisms. For example, soil augmented with compost may directly supply limiting nutrients for the plant. Likewise, compost may alter the soil microbe interactions and indirectly lead to protection against harmful pathogens. This can be through competition or antibiosis, hyperparasitism and ISR (Hoitink and Boehm 1999). One of the most significant indirect modes of action is likely through modification of soil microbial activity and 


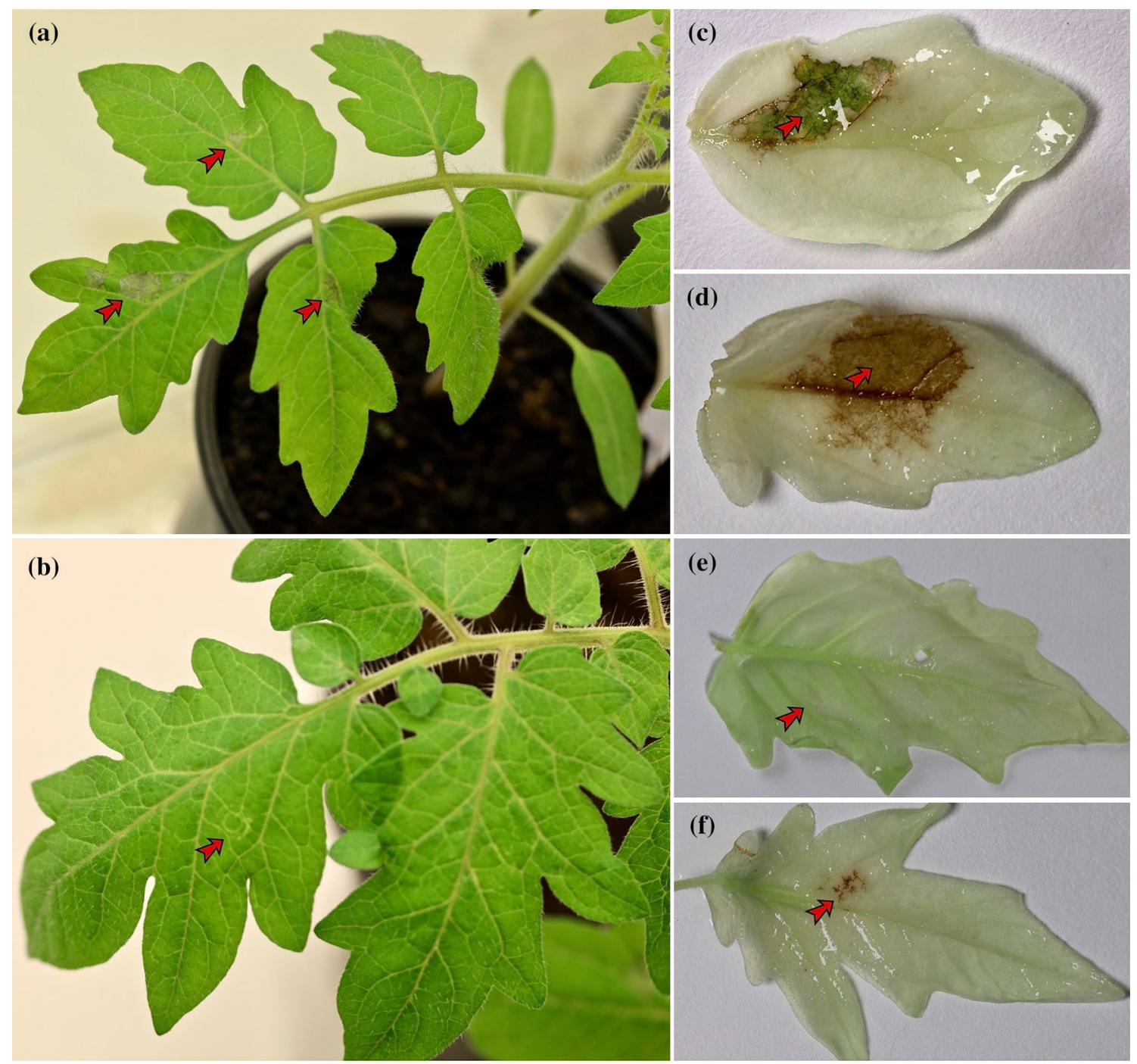

Fig. 4 Symptoms of 4-week-old Moneymaker tomato plants from infection by $P$. infestans isolate, D12-2. The red arrows indicate the location of infiltration/loading of $P$. infestans zoospores. a The tomato seed planted in un-amended soil. b The seed planted in oak-barkcompost-amended soil, combined with B. subtilis subsp. subtilis. c A bleached leaflet of an untreated control plant in the whole plant assay.

composition (Noble and Coventry 2005). In this study, we detected known endophytes in the oak-bark compost. The antimicrobial activity and potential of endophytes to control disease have been reported for several plant pathogens, including $P$. infestans in tomato (Kim et al. 2007; Miles et al. 2012). We recovered fungal species including $A$. placitae, $M$. elongata and $P$. cyclaminis in the oak-bark compost. Antennariella placitae has been shown to have significant antagonistic activity against Ustilagonoidea virens (Cooke) Takah on rice (Andargie et al. 2017). Mortierella elongate is usually found in soil, and has been reported to improve soil health and increase regulation of plant growth hormones (Li et al. 2018). Phialophora cyclaminis has been isolated d A bleached leaflet of an untreated control plant in detached leaf assay. e A bleached leaflet of the plant that was treated with a combination of oak-bark compost and B. subtilis subsp. subtilis in whole plant assay. f A bleached leaflet of the plant that was treated with a combination of oak-bark compost and B. subtilis subsp. subtilis in the detached leaf assay

from the rhizosphere of common oak and has been shown to have antifungal activity (Kaneto et al. 1993; Kwaśna 2001). We also detected bacterial species including E. cloacae and P. validus in the compost. Enterobacter cloacae is a PGPR and has been reported to be an effective biocontrol agent against soilborne pathogens such as Pythium ultimum Trow and Phytophthora capsici L. (Nelson and Maloney 1992; Toh et al. 2016). This bacterial agent has also been shown to enhance tomato resistance to $R$. solanacearum (Upreti and Thomas 2015). Paenibacillus validus, isolated from composts, has been reported to have cellulase and ligninase activities which are important for the composting process (Hemati et al. 2018). This bacterium has been shown to 


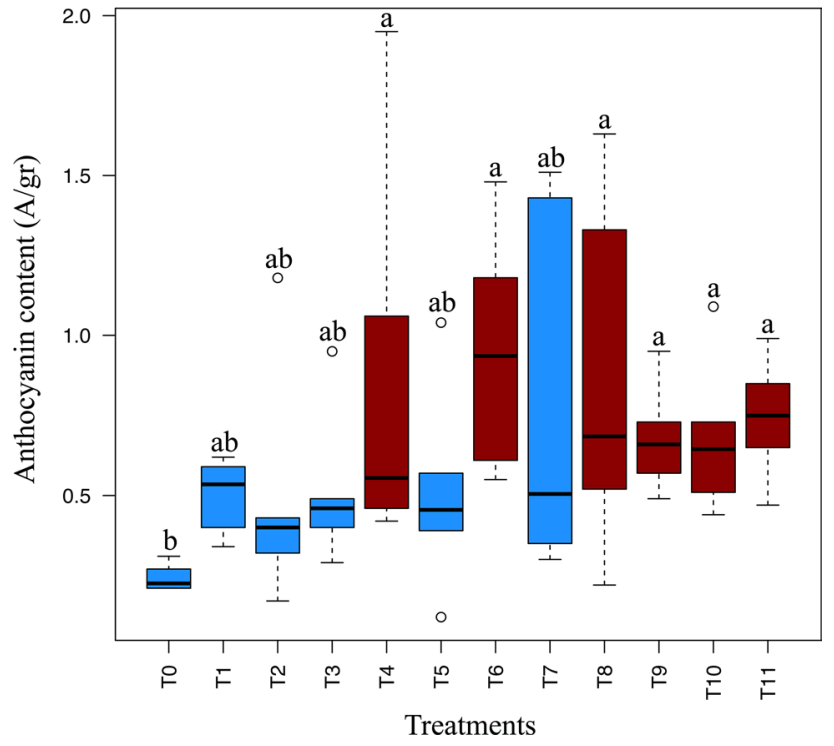

Fig. 5 Effect of the 12 treatments on anthocyanin accumulation in tomato leaflets. Six biological replicates were analyzed for each treatment. Anthocyanins (A) were evaluated by measuring the absorbance at 530 and $657 \mathrm{~nm}$. The treatments that differ significantly from the untreated control are indicated in red and the treatments that do not differ significantly from untreated control are indicated in blue. Boxplots with the same letters do not differ significantly at $P=0.05$

reduce the number of live Candidatus Liberibacter asiaticus (Citrus Huanglongbing pathogen) cells (Trivedi et al. 2011). In our study, oak-bark compost enhanced plant resistance to $P$. infestans in whole plant and detached leaf assays. This may be linked to the activation of ISR or the production of metabolites by endophytes present in the compost. Another factor that can contribute in the success of plant protection is the use of a large volume of composts ( $>15 \%$ ) (Noble and Coventry 2005; Bahramisharif et al. 2013), due to an increase in microbial community. In our study, we used a $25 \%(\mathrm{v} / \mathrm{v})$ of oak-bark compost.

Plant growth and protection were also present in treatments with $B$. subtilis subsp. subtilis. This Gram-positive bacterial strain is one of the major PGPRs that has shown promise for increasing crop yields. A number of mechanisms for plant growth promotion and pathogen protection have been proposed for $B$. subtilis subsp. subtilis, including the production of phytohormones, delivery of nutrients and stimulation of the ISR (Beneduzi et al. 2012; Pieterse et al. 2014). In prior studies on tomato seedlings, $B$. subtilis has been shown to be effective in promoting growth which may be due to an increase in plant hormone production such as indole-3-acetic acid (IAA) and gibberellic acid $\left(\mathrm{GA}_{3}\right)$ (Chowdappa et al. 2013; Cendales et al. 2017). In our study, plants treated with $B$. subtilis subsp. subtilis were 2.5 -fold larger in biomass. Furthermore, the growth promotion was significantly enhanced when $B$. subtilis subsp. subtilis was combined with the compost. A recent study by Rao et al. (2017) found that $B$. subtilis enriched vermicompost treatment increase carrot (Daucus carota subsp. sativus Hoffm.) yields by $28.8 \%$.

Likewise, $B$. subtilis proved to be effective for enhancing plant resistance under biotic stress. In our study, tomato plants treated with $B$. subtilis were resistant to the pathogen not only in the whole plant assays, but also in detached leaf assays. This indicates that the beneficial effect was most likely through a systemic plant response, because $B$. subtilis was not detected in the detached leaf tissue, where the pathogen challenge took place. Plant resistance was further enhanced by the application of B. subtilis subsp. subtilis enriched oak-bark compost in both whole plant and detached leaf assays. This may be due to the improvement in root colonization by the bio-agent, as compost provides additional nutrition for the bacteria. The application of combined B. subtilis and vermicompost has been shown to be effective in the reduction of nematode population and soft rot disease incidence in carrot (Rao et al. 2017). The combination of composts and biological agents has been reported for a few soilborne pathogens and P. capsici on several crops including beans (Phaseolus vulgaris L.), onion (Allium cepa L.), pepper (Capsicum annuиm L.), rooibos (Aspalathus linearis (N.L. Burm.) R. Dahlgr.) and turf grass (Nakasaki et al. 1998; Chae et al. 2006; Coventry et al. 2006; Pugliese et al. 2011; Bahramisharif et al. 2013). The co-inoculation of compost with B. subtilis subsp. subtilis could enhance the consistency in disease suppression, as also reviewed previously (Noble 2011). Here, anthocyanin accumulation in leaflet of plants treated with either B. subtilis subsp. subtilis or in combination with the compost was not enhanced. Anthocyanins are commonly upregulated in response to plant stress caused by biotic or abiotic factors (Dixon and Paiva 1995; de Vries et al. 2018). However, similar to this study, Yoon et al. (2015) found a reduction in the total anthocyanin content after black rice bran was fermented with $B$. subtilis. Likewise, the anthocyanin level was decreased in B. subtilis fermented pigeon pea (Lee et al. 2015). This may be due to the hydrolysis of anthocyanin glycosides by $\beta$-glucosidase produced by B. subtilis (Asha et al. 2015).

Treatment with Trichoderma harzianum stimulated plant growth and protected plants from $P$. infestans, but only in whole plant assays. The plant protection by $T$. harzianum was not as great as when plants were treated with $B$. subtilis subsp. subtilis, in both whole plant and detached leaf assays. In contrast, $T$. harzianum has been reported to have greater potential for suppressing late blight disease incidence and severity in potato than B. subtilis (Wharton et al. 2012). The mode of action for growth promotion and plant protection by $T$. harzianum in whole plant assays may involve mycoparasitism, antibiotic production, competition, enzyme biosynthesis or ISR (Howell 2003). In this study, the level 
of anthocyanin was elevated in treatments that included $T$. harzianum. In other studies, plants exposed to volatiles of Trichoderma showed elevated levels of anthocyanin levels and were more resistant to Botrytis cinerea and Alternaria brassicicola (Schwein.) Wiltshire (Kottb et al. 2015). The application of T. harzianum in combination with oak-bark compost negatively affected the root growth and resulted in significantly higher disease severity in both whole plant and detached leaf assays. Likewise, on other crops, the coinoculation of $T$. harzianum with compost was shown to be ineffective at suppressing P. ultimum in cucumber and Phytophthora nicotianae Breda de Haan in tomato (Pugliese et al. 2011). One hypothesis for the negative impact in the combined treatment is that $T$. harzianum competes with or acts antagonistically on the beneficial members of the microbial community in the compost, leading to an increase in disease severity. On the other hand, the co-inoculation of T. harzianum and compost has been reported to improve saline soil quality (Mbarki et al. 2017). In the current study, it was notable that the negative impact of the combined $T$. harzianum and compost treatment could be nullified if $B$. subtilis subsp. subtilis was also added, suggesting that this bacterial agent is insensitive to T. harzianum.

Variation in tomato growth and protection was observed for the two commercial products, FZB24 and FZB42. In general, FZB24 positively impacted growth more than FZB42. Previously, Gül et al. (2008) showed that the two strains of $B$. amyloliquefaciens, FZB24 and FZB42, increased tomato yield by nearly $10 \%$ in the open hydroponic system; but, they both did not affect plant growth in the closed hydroponic system. Tryptophan-dependent synthesis of IAA has been implicated for the stimulation of plant growth by B. amyloliquefaciens (Idris et al. 2004, 2007). The FZB24 product was also better at plant protection than FZB42 in whole plant assays. However, none of these products were able to suppress late blight in detached leaf assays, which may be explained by the failure of these products to induce systemic defense in the host. The use of FZB24 has been reported to be effective in reducing disease caused by the oomycete Pythium aphanidermatum (Edson) Fitzp. at early stages in a hydroponic system of tomato (Grosch et al. 1999). In tomato plants, FZB24 product has also been shown to be effective against Fusarium crown and root rot (Myresiotis et al. 2012). Furthermore, FZB24 was tested against Tilletia tritici (Bjerk.) G. Winter, the causal agent of common bunt in wheat, and showed some beneficial activity under controlled conditions, but not in the field (Koch et al. 2006). The FZB42 product has been found to have antifungal activity towards Fusarium graminearum Schwabe which causes Fusarium head blight in cereal crops (Gu et al. 2017). The mechanisms involved in disease suppression by these products may be related to the enhancement of plant physical status through expression and upregulation of plant's defense compounds and genes, leading to plant stress-resistance, disease-resistance and growth (Xie et al. 2017). In the current study, FZB24 and FZB42 significantly increased anthocyanin content in tomato plants. The use of Bacillus amyloliquefaciens has been shown to significantly improve growth, yield and quality of strawberry fruits due to an increase in the level of natural antioxidants such as anthocyanins (Rahman et al. 2018). Other factors that can possibly be associated with disease suppression are the production of antifungal compounds such as Bacillomycin D (Gu et al. 2017) or the secretion of proteins such as acetolactate synthase (AlsS) by B. amyloliquefaciens that elicit plant innate immunity (Kierul et al. 2015). The co-inoculation of oak-bark compost and the commercial products resulted in an increase in plant growth but did not enhance plant protection further, compared to each product alone. It was also notable that compared to the untreated control, compost significantly decreased the level of anthocyanin when combined with the commercial products.

In conclusion, this study showed that oak-bark compost as a standalone treatment or in combination with $B$. subtilis subsp. subtilis and commercial products can be effective in enhancing tomato growth and resistance under biotic stress conditions. The combination of the compost and $B$. subtilis subsp. subtilis showed the greatest promise for obtaining better growth and more effective and consistent plant protection, although this did not correspond to higher levels of anthocyanin in leaves. Future research should determine the mechanistic basis for plant growth promotion and protection in the combination treatment of oak-bark compost with $B$. subtilis subsp. subtilis.

Author contribution statement $\mathrm{AB}$ and LER conceived and designed research. AB conducted experiments and analyzed data. AB wrote the manuscript. All authors read and approved the manuscript.

Acknowledgements This work was supported by German Academic Exchange Service [57145465]. AB gratefully acknowledge funding through International Graduate School in Plant Sciences. We would like to thank Ian Beddows and Chris Spies for their valuable comments on this study; Francine Govers (Wageningen University) for P. infestans isolate D12-2 and Janina von Dahlen for providing the Phytophthora strain; and Predrag Marinovski for technical assistance.

\section{Compliance with ethical standards}

Conflict of interest The authors declare that they have no competing interests.

Open Access This article is distributed under the terms of the Creative Commons Attribution 4.0 International License (http://creativeco mmons.org/licenses/by/4.0/), which permits unrestricted use, distribution, and reproduction in any medium, provided you give appropriate credit to the original author(s) and the source, provide a link to the Creative Commons license, and indicate if changes were made. 


\section{References}

Agrios GN (2005) Plant pathology, 5th edn. Academic Press, San Diego

An Y, Kang SC, Kim KD, Hwang BK, Jeun Y (2010) Enhanced defense responses of tomato plants against late blight pathogen Phytophthora infestans by pre-inoculation with rhizobacteria. Crop Prot 29:1406-1412. https://doi.org/10.1016/j.cropro.2010.07.023

Andargie M, Congyi Z, Yun Y, Li J (2017) Identification and evaluation of potential bio-control fungal endophytes against Ustilagonoidea virens on rice plants. World J Microb Biot 33:120. https://doi. org/10.1007/s11274-017-2273-y

Arenz BE, Schlatter DC, Bradeen JM, Kinkel LL (2015) Blocking primers reduce co-amplification of plant DNA when studying bacterial endophyte communities. J Microbiol Meth 117:1-3. https:// doi.org/10.1016/j.mimet.2015.07.003

Asha B, Pathma J, Sakthivel N (2015) Isolation and characterization of a novel thermostable $\beta$-glucosidase from Bacillus subtilis SU40. Appl Biochem Micro 51:21-26. https://doi.org/10.1134/S0003 683815010032

Bahramisharif A, Lamprecht SC, Calitz F, McLeod A (2013) Suppression of Pythium and Phytophthora damping-off of rooibos by compost and a combination of compost and nonpathogenic Pythium Taxa. Plant Dis 97:1605-1610. https://doi.org/10.1094/ pdis-04-13-0360-re

Beneduzi A, Ambrosini A, Passaglia LMP (2012) Plant growth-promoting rhizobacteria (PGPR): their potential as antagonists and biocontrol agents. Genet Mol Biol 35:1044-1051. https://doi. org/10.1590/S1415-47572012000600020

Benhamou N, Rey P, Picard K, Tirilly Y (1999) Ultrastructural and cytochemical aspects of the interaction between the mycoparasite Pythium oligandrum and soilborne plant pathogens. Phytopathology 89:506-517. https://doi.org/10.1094/phyto.1999.89.6.506

Benitez T, Rincon AM, Limon MC, Codon AC (2004) Biocontrol mechanisms of Trichoderma strains. Int Microbiol 7:249-260

Caten C, Jinks J (1968) Spontaneous variability of single isolates of Phytophthora infestans. I. Cultural variation. Can J Botany 46:329-348. https://doi.org/10.1139/b68-055

Cendales TC, Gonzalez CAR, Cuasquer CPV, Alzate OAT, Rodriguez AH (2017) Bacillus effect on the germination and growth of tomato seedlings (Solanum lycopersicum L). Acta Biol Colomb 22:37-44. https://doi.org/10.15446/abc.v22n1.57375

Chae DH, De Jin R, Hwangbo H, Kim YW, Kim YC, Park RD, Krishnan HB, Kim KY (2006) Control of late blight (Phytophthora capsici) in pepper plant with a compost containing multitude of chitinase-producing bacteria. Biocontrol 51:339-351. https://doi.org/10.1007/s10526-005-2934-X

Chowdappa P, Kumar SPM, Lakshmi MJ, Upreti KK (2013) Growth stimulation and induction of systemic resistance in tomato against early and late blight by Bacillus subtilis OTPB1 or Trichoderma harzianum OTPB3. Biol Control 65:109-117. https://doi. org/10.1016/j.biocontrol.2012.11.009

Cooke D, Drenth A, Duncan J, Wagels G, Brasier C (2000) A molecular phylogeny of Phytophthora and related oomycetes. Fungal Genet Biol 30:17-32. https://doi.org/10.1006/fgbi.2000.1202

Coventry E, Noble R, Mead A, Marin FR, Perez JA, Whipps JM (2006) Allium white rot suppression with composts and Trichoderma viride in relation to sclerotia viability. Phytopathology 96:10091020. https://doi.org/10.1094/phyto-96-1009

de Vries S, von Dahlen JK, Uhlmann C, Schnake A, Kloesges T, Rose LE (2017) Signatures of selection and host-adapted gene expression of the Phytophthora infestans RNA silencing suppressor PSR2. Mol Plant Pathol 18:110-124. https://doi.org/10.1111/ mpp. 12465 de Vries S, von Dahlen JK, Schnake A, Ginschel S, Schulz B, Rose LE (2018) Broad-spectrum inhibition of Phytophthora infestans by fungal endophytes. FEMS Microbiol Ecol 94:fiy37. https://doi. org/10.1093/femsec/fly037

Dixon RA, Paiva NL (1995) Stress-induced phenylpropanoid metabolism. Plant Cell 7:1085. https://doi.org/10.1105/tpc.7.7.1085

Edwards K, Johnstone C, Thompson C (1991) A simple and rapid method for the preparation of plant genomic DNA for PCR analysis. Nucleic Acids Res 19:1349. https://doi.org/10.1093/ nar/19.6.1349

Fry WE, Birch PRJ, Judelson HS, Grunwald NJ, Danies G, Everts KL, Gevens AJ, Gugino BK, Johnson DA, Johnson SB, McGrath MT, Myers KL, Ristaino JB, Roberts PD, Secor G, Smart CD (2015) Five reasons to consider Phytophthora infestans a reemerging pathogen. Phytopathology 105:966-981. https://doi.org/10.1094/phyto-01-15-0005-fi

Grosch R, Junge H, Krebs B, Bochow H (1999) Use of Bacillus subtilis as a biocontrol agent. III. Influence of Bacillus subtilis on fungal root diseases and on yield in soilless culture. J Plant Dis Protect 106:568-580

Gu Q, Yang Y, Yuan Q, Shi G, Wu L, Lou Z, Huo R, Wu H, Borriss R, Gao X (2017) Bacillomycin D produced by Bacillus amyloliquefaciens is involved in the antagonistic interaction with the plant-pathogenic fungus Fusarium graminearum. Appl Environ Microb 83:e01075-17. https://doi.org/10.1128/ AEM.01075-17

Gül A, Kidoglu F, Tüzel Y (2008) Effects of nutrition and Bacillus amyloliquefaciens on tomato (Solanum lycopersicum L.) growing in perlite. Span J Agric Res 6:422-429. https://doi.org/10.5424/ sjar/2008063-335

Gutierrez-Miceli FA, Santiago-Borraz J, Molina JAM, Nafate CC, Abud-Archila M, Llaven MAO, Rincon-Rosales R, Dendooven L (2007) Vermicompost as a soil supplement to improve growth, yield and fruit quality of tomato (Lycopersicum esculentum). Bioresour Technol 98:2781-2786. https://doi.org/10.1016/j.biort ech.2006.02.032

Haverkort AJ, Struik PC, Visser RGF, Jacobsen E (2009) Applied Biotechnology to combat late blight in potato caused by Phytophthora Infestans. Potato Res 52:249-264. https://doi.org/10.1007/s1154 0-009-9136-3

Hemati A, Aliasgharzad N, Khakvar R (2018) In vitro evaluation of lignocellulolytic activity of thermophilic bacteria isolated from different composts and soils of Iran. Biocatal Agric Biotechnol 14:424-430. https://doi.org/10.1016/j.bcab.2018.04.010

Hoitink HAJ, Boehm MJ (1999) Biocontrol within the context of soil microbial communities: a substrate-dependent phenomenon. Annu Rev Phytopathol 37:427-446. https://doi.org/10.1146/annur ev.phyto.37.1.427

Hoitink HAJ, Stone AG, Han DY (1997) Suppression of plant diseases by composts. HortScience 32:184-187

Horner NR, Grenville-Briggs LJ, Van West P (2012) The oomycete Pythium oligandrum expresses putative effectors during mycoparasitism of Phytophthora infestans and is amenable to transformation. Fungal Biol 116:24-41. https://doi.org/10.1016/j.funbi o.2011.09.004

Howell CR (2003) Mechanisms employed by Trichoderma species in the biological control of plant diseases: the history and evolution of current concepts. Plant Dis 87:4-10. https://doi.org/10.1094/ pdis.2003.87.1.4

Hudspeth DSS, Nadler SA, Hudspeth MES (2000) A COX2 molecular phylogeny of the peronosporomycetes. Mycologia 92:674-684. https://doi.org/10.2307/3761425

Idris EE, Bochow H, Ross H, Borriss R (2004) Use of Bacillus subtilis as biocontrol agent. VI. Phytohormonelike action of culture filtrates prepared from plant growth-promoting Bacillus 
amyloliquefaciens FZB24, FZB42, FZB45 and Bacillus subtilis FZB37. J Plant Dis Protect 111:583-597

Idris EE, Iglesias DJ, Talon M, Borriss R (2007) Tryptophan-dependent production of indole-3-acetic acid (IAA) affects level of plant growth promotion by Bacillus amyloliquefaciens FZB42. Mol Plant-Microbe Interact 20:619-626. https://doi.org/10.1094/ MPMI-20-6-0619

Iqbal MK, Shafiq T, Hussain A, Ahmed K (2010) Effect of enrichment on chemical properties of MSW compost. Bioresource Technol 101:5969-5977. https://doi.org/10.1016/j.biort ech.2010.02.105

Janvier C, Villeneuve F, Alabouvette C, Edel-Hermann V, Mateille T, Steinberg C (2007) Soil health through soil disease suppression: which strategy from descriptors to indicators? Soil Biol Biochem 39:1-23. https://doi.org/10.1016/j.soilbio.2006.07.001

Judelson HS, Blanco FA (2005) The spores of Phytophthora: weapons of the plant destroyer. Nat Rev Microbiol 3:47-58. https://doi. org/10.1038/nrmicro1064

Kabir L, Kim SW, Kim YS, Lee YS (2013) Biocontrol of late blight and plant growth promotion in tomato using rhizobacterial isolates. J Microbiol Biotechnol 23:897-904. https://doi.org/10.4014/ jmb.1209.09069

Kaneto R, Chiba H, Agematu H, Shibamoto N, Yoshioka T, Nishida H, Okamoto R (1993) Mer-WF3010, a new member of the papulacandin family. J Antibiot 46:247-250

Kearse M, Moir R, Wilson A, Stones-Havas S, Cheung M, Sturrock S, Buxton S, Cooper A, Markowitz S, Duran C, Thierer T, Ashton B, Meintjes P, Drummond A (2012) Geneious basic: an integrated and extendable desktop software platform for the organization and analysis of sequence data. Bioinformatics 28:1647-1649. https:// doi.org/10.1093/bioinformatics/bts199

Kierul K, Voigt B, Albrecht D, Chen X-H, Carvalhais LC, Borriss R (2015) Influence of root exudates on the extracellular proteome of the plant growth-promoting bacterium Bacillus amyloliquefaciens FZB42. Microbiology 161:131-147. https://doi.org/10.1099/ mic.0.083576-0

Kim HY, Choi GJ, Lee HB, Lee SW, Lim HK, Jang KS, Son SW, Lee SO, Cho KY, Sung ND, Kim JC (2007) Some fungal endophytes from vegetable crops and their anti-oomycete activities against tomato late blight. Lett Appl Microbiol 44:332-337. https://doi. org/10.1111/j.1472-765X.2006.02093.x

Kloepper JW, Ryu CM, Zhang SA (2004) Induced systemic resistance and promotion of plant growth by Bacillus spp. Phytopathology 94:1259-1266. https://doi.org/10.1094/phyto.2004.94.11.1259

Koch E, Weil B, Wachter R, Wohlleben S, Spiess H, Krauthausen HJ (2006) Evaluation of selected microbial strains and commercial alternative products as seed treatments for the control of Tilletia tritici, Fusarium culmorum, Drechslera graminea and D. teres. J Plant Dis Protect 113:150-158. https://doi.org/10.1007/BF033 56172

Kone SB, Dionne A, Tweddell RJ, Antoun H, Avis TJ (2010) Suppressive effect of non-aerated compost teas on foliar fungal pathogens of tomato. Biol Control 52:167-173. https://doi.org/10.1016/j. biocontrol.2009.10.018

Kottb M, Gigolashvili T, Großkinsky DK, Piechulla B (2015) Trichoderma volatiles effecting Arabidopsis: from inhibition to protection against phytopathogenic fungi. Front Microbiol 6:995. https ://doi.org/10.3389/fmicb.2015.00995

Kwaśna H (2001) Fungi in the rhizosphere of common oak and its stumps and their possible effect on infection by Armillaria. Appl Soil Ecol 17:215-227. https://doi.org/10.1016/S0929 $-1393(01) 00137-8$

Lamprecht SC, Tewoldemedhin YT (2017) Fusarium species associated with damping-off of rooibos seedlings and the potential of compost as soil amendment for disease suppression. S Afr J Bot 110:110-117. https://doi.org/10.1016/j.sajb.2016.07.009
Lee B-H, Lai Y-S, Wu S-C (2015) Antioxidation, angiotensin converting enzyme inhibition activity, nattokinase, and antihypertension of Bacillus subtilis (natto)-fermented pigeon pea. J Food Drug Anal 23:750-757. https://doi.org/10.1016/j.jfda.2015.06.008

Levene H (1961) Robust tests for equality of variances. In: Olkin I (ed) Contributions to probability and statistics. Stanford University Press, Palo Alto, CA, pp 279-292

Lewis JA, Lumsden RD, Millner PD, Keinath AP (1992) Suppression of damping-off of peas and cotton in the field with composted sewage-sludge. Crop Prot 11:260-266. https://doi.org/10.1016/02612194(92)90047-9

Li F, Chen L, Redmile-Gordon M, Zhang J, Zhang C, Ning Q, Li W (2018) Mortierella elongata's roles in organic agriculture and crop growth promotion in a mineral soil. Land Degrad Dev 29:16421651. https://doi.org/10.1002/ldr.2956

Lindoo SJ, Caldwell MM (1978) Ultraviolet-B radiation-induced inhibition of leaf expansion and promotion of anthocyanin production: lack of involvement of the low irradiance phytochrome system. Plant Physiol 61:278-282

Martinez-Medina A, Fernandez I, Sanchez-Guzman MJ, Jung SC, Pascual JA, Pozo MJ (2013) Deciphering the hormonal signaling network behind the systemic resistance induced by Trichoderma harzianum in tomato. Front Plant Sci 4:12. https://doi. org/10.3389/fpls.2013.00206

Matson MEH, Small IM, Fry WE, Judelson HS (2015) Metalaxyl resistance in Phytophthora infestans: assessing role of RPA190 gene and diversity within clonal lineages. Phytopathology 105:1594-1600. https://doi.org/10.1094/phyto-05-15-0129-r

Mbarki S, Cerda A, Brestic M, Mahendra R, Abdelly C, Pascual JA (2017) Vineyard compost supplemented with Trichoderma harzianum T78 improve saline soil quality. Land Degrad Dev 28:1028 1037. https://doi.org/10.1002/ldr.2554

Mengesha WK, Powell SM, Evans KJ, Barry KM (2017) Diverse microbial communities in non-aerated compost teas suppress bacterial wilt. World J Microbiol Biotechnol 33:14. https://doi. org/10.1007/s11274-017-2212-y

Miles LA, Lopera CA, Gonzalez S, de Garcia MCC, Franco AE, Restrepo S (2012) Exploring the biocontrol potential of fungal endophytes from an Andean Colombian Paramo ecosystem. Biocontrol 57:697-710. https://doi.org/10.1007/s10526-012-9442-6

Myresiotis CK, Karaoglanidis GS, Vryzas Z, Papadopoulou-Mourkidou E (2012) Evaluation of plant-growth-promoting rhizobacteria, acibenzolar-S-methyl and hymexazol for integrated control of Fusarium crown and root rot on tomato. Pest Manag Sci 68:404411. https://doi.org/10.1002/ps. 2777

Nakamura L, Roberts MS, Cohan FM (1999) Note: relationship of Bacillus subtilis clades associated with strains 168 and W23: A proposal for Bacillus subtilis subsp. subtilis subsp. nov. and Bacillus subtilis subsp. spizizenii subsp. nov. Int J Syst Evol Micr 49:1211-1215. https://doi.org/10.1099/00207713-49-3-1211

Nakasaki K, Hiraoka S, Nagata H (1998) A new operation for producing disease-suppressive compost from grass clippings. Appl Environ Microb 64:4015-4020

Nelson EB, Maloney AP (1992) Molecular approaches for understanding biological control mechanisms in bacteria: studies of the interaction of Enterobacter cloacae with Pythium ultimum. Can J Plant Pathol 14:106-114. https://doi.org/10.1080/07060669209500911

Noble R (2011) Risks and benefits of soil amendment with composts in relation to plant pathogens. Australas Plant Path 40:157-167. https://doi.org/10.1007/s13313-010-0025-7

Noble R, Coventry E (2005) Suppression of soil-borne plant diseases with composts: a review. Biocontrol Sci Techn 15:3-20. https:// doi.org/10.1080/09583150400015904

O'Brien PA (2017) Biological control of plant diseases. Australas Plant Path 46:293-304. https://doi.org/10.1007/s13313-017-0481-4 
Perelló AE, Moreno MV, Mónaco C, Simón MR, Cordo C (2009) Biological control of Septoria tritici blotch on wheat by Trichoderma spp. under field conditions in Argentina. Biocontrol 54:113-122. https://doi.org/10.1007/s10526-008-9159-8

Pieterse CMJ, Zamioudis C, Berendsen RL, Weller DM, Van Wees SCM, Bakker P (2014) Induced systemic resistance by beneficial microbes. Annu Rev Phytopathol 52:347-375. https://doi. org/10.1146/annurev-phyto-082712-102340

Pugliese M, Liu BP, Gullino ML, Garibaldi A (2011) Microbial enrichment of compost with biological control agents to enhance suppressiveness to four soil-borne diseases in greenhouse. J Plant Dis Protect 118:45-50. https://doi.org/10.1007/BF03356380

Rahman M, Sabir AA, Mukta JA, Khan MMA, Mohi-Ud-Din M, Miah MG, Rahman M, Islam MT (2018) Plant probiotic bacteria Bacillus and Paraburkholderia improve growth, yield and content of antioxidants in strawberry fruit. Sci Rep 8:2504. https://doi. org/10.1038/s41598-018-20235-1

Rao MS, Kamalnath M, Umamaheswari R, Rajinikanth R, Prabu P, Priti K, Grace GN, Chaya MK, Gopalakrishnan C (2017) Bacillus subtilis IIHR BS-2 enriched vermicompost controls root knot nematode and soft rot disease complex in carrot. Sci Hortic 218:56-62. https://doi.org/10.1016/j.scienta.2017.01.051

Rozen S, Skaletsky H (2000) Primer3 on the WWW for general users and for biologist programmers. In: Minsener S, Krawetz SA (eds) Bioinformatics methods and protocols. Methods in molecular biology, vol 132. Humana Press, Totowa, pp 365-386

Ryan AD, Kinkel LL, Schottel JL (2004) Effect of pathogen isolate, potato cultivar, and antagonist strain on potato scab severity and biological control. Biocontrol Sci Technol 14:301-311. https:// doi.org/10.1080/09583150410001665187

Saravanakumar K, Fan LL, Fu KH, Yu CJ, Wang M, Xia H, Sun JA, Li YQ, Chen J (2016) Cellulase from Trichoderma harzianum interacts with roots and triggers induced systemic resistance to foliar disease in maize. Sci Rep 6:35543. https://doi.org/10.1038/ srep35543

Saville A, Graham K, Grünwald NJ, Myers K, Fry WE, Ristaino JB (2015) Fungicide sensitivity of US genotypes of Phytophthora infestans to six oomycete-targeted compounds. Plant Dis 99:659666. https://doi.org/10.1094/PDIS-05-14-0452-RE

Schummer C, Salquebre G, Briand O, Millet M, Appenzeller BMR (2012a) Determination of farm workers' exposure to pesticides by hair analysis. Toxicol Lett 210:203-210. https://doi.org/10.1016/j. toxlet.2011.11.019

Schummer C, Tuduri L, Briand O, Appenzeller BM, Millet M (2012b) Application of XAD-2 resin-based passive samplers and SPMEGC-MS/MS analysis for the monitoring of spatial and temporal variations of atmospheric pesticides in Luxembourg. Environ Pollut 170:88-94. https://doi.org/10.1016/j.envpol.2012.05.025

Shapiro SS, Wilk MB (1965) An analysis of variance test for normality (complete samples). Biometrika 52:591-611

Taylor RJ, Salas B, Secor GA, Rivera V, Gudmestad NC (2002) Sensitivity of north American isolates of Phytophthora erythroseptica and Pythium ultimum to mefenoxam (metalaxyl). Plant Dis 86:797-802. https://doi.org/10.1094/pdis.2002.86.7.797

Termorshuizen AJ, van Rijn E, van der Gaag DJ, Alabouvette C, Chen Y, Lagerlof J, Malandrakis AA, Paplomatas EJ, Ramert
B, Ryckeboer J, Steinberg C, Zmora-Nahum S (2006) Suppressiveness of 18 composts against 7 pathosystems: variability in pathogen response. Soil Biol Biochem 38:2461-2477. https://doi. org/10.1016/j.soilbio.2006.03.002

Tewoldemedhin Y, Lamprecht S, Mazzola M (2015) Rhizoctonia anastomosis groups associated with diseased rooibos seedlings and the potential of compost as soil amendment for disease suppression. Plant Dis 99:1020-1025. https://doi.org/10.1094/ PDIS-11-14-1211-RE

Toh S, Samuel L, Awang A (2016) Screening for antifungal-producing bacteria from Piper nigrum plant against Phytophthora capsici. Int Food Res J 23:2616-2622

Trivedi P, Spann T, Wang N (2011) Isolation and characterization of beneficial bacteria associated with citrus roots in Florida. Microb Ecol 62:324-336. https://doi.org/10.1007/s00248-011-9822-y

Tukey JW (1949) Comparing individual means in the analysis of variance. Biometrics 5:99-114

Upreti R, Thomas P (2015) Root-associated bacterial endophytes from Ralstonia solanacearum resistant and susceptible tomato cultivars and their pathogen antagonistic effects. Front Microbiol 6:255. https://doi.org/10.3389/fmicb.2015.00255

Wharton PS, Kirk WW, Schafer RL, Tumbalam P (2012) Evaluation of biological seed treatments in combination with management practices for the control of seed-borne late blight in potato. Biol Control 63:326-332. https://doi.org/10.1016/j.biocontrol.2012.09.005

White TJ, Bruns T, Lee S, Taylor J (1990) Amplification and direct sequencing of fungal ribosomal RNA genes for phylogenetics. In: Innis MA, Gelfand DH, Sninsky JJ, White TJ (eds) PCR protocols: a guide to methods and applications. Academic Press, New York, pp 315-322

Williams J, Clarkson JM, Mills PR, Cooper RM (2003) A selective medium for quantitative reisolation of Trichoderma harzianum from Agaricus bisporus compost. Appl Environ Microb 69:41904191. https://doi.org/10.1128/AEM.69.7.4190-4191.2003

Xie Y, Wu L, Zhu B, Wu H, Gu Q, Rajer FU, Gao X (2017) Digital gene expression profiling of the pathogen-resistance mechanism of Oryza sativa 9311 in response to Bacillus amyloliquefaciens FZB42 induction. Biol Control 110:89-97. https://doi. org/10.1016/j.biocontrol.2017.04.009

Xu XM, Jeffries P, Pautasso M, Jeger MJ (2011) Combined use of biocontrol agents to manage plant diseases in theory and practice. Phytopathology 101:1024-1031. https://doi.org/10.1094/ phyto-08-10-0216

Yan ZN, Reddy MS, Ryu CM, McInroy JA, Wilson M, Kloepper JW (2002) Induced systemic protection against tomato late blight elicited by plant growth-promoting rhizobacteria. Phytopathology 92:1329-1333. https://doi.org/10.1094/phyto.2002.92.12.1329

Yao YP, Li Y, Chen ZQ, Zheng BQ, Zhang LT, Niu B, Meng JL, Li AJ, Zhang JM, Wang Q (2016) Biological control of potato late blight using isolates of Trichoderma. Am J Potato Res 93:33-42. https://doi.org/10.1007/s12230-015-9475-3

Yoon HJ, Lee KA, Lee JH, Jin HJ, Kim HJ, Kim KT, Paik HD (2015) Effect of fermentation by Bacillus subtilis on antioxidant and cytotoxic activities of black rice bran. Int J Food Sci Tech 50:612-618. https://doi.org/10.1111/ijfs. 12693 